\title{
Spørsmål om legemiddelbruk i de store befolkningsundersøkelsene - fra enkeltspørsmål til full oversikt
}

\author{
Svetlana Skurtveit ${ }^{1}$, Kari Furu ${ }^{1,2}$, Elin O. Rosvold ${ }^{2}$ og Jørund Straand ${ }^{2}$ \\ ${ }^{1}$ Avdeling for legemidler, Divisjon for epidemiologi, Nasjonalt folkehelseinstitutt, Oslo \\ ${ }^{2}$ Institutt for allmenn- og samfunnsmedisin, Universitetet $i$ Oslo \\ Korrespondanse til: Svetlana Skurtveit, Avdeling for legemidler, Divisjon for epidemiologi, Nasjonalt folkehelseinstitutt, \\ Postboks 4404 Nydalen, 0403 Oslo \\ Telefon: 23408172 Telefaks: 23408260 E-post: svetlana.skurtveit@fhi.no
}

\begin{abstract}
SAMMENDRAG
En oversikt over legemiddelspørsmålene brukt i ulike helseundersøkelser gjennomført i regi av Statens helseundersøkelser (nå en del av Nasjonalt folkehelseinstitutt) presenteres med fokus på de legemiddelspørsmålene som inngår i helseundersøkelser i nettverket CONOR (COhort of NORway). Spørsmålene om legemiddelbruk i helseundersøkelsene har gjennomgått store forandringer fra 1974 og fram til i dag. Ved de første undersøkelsene ble bare bruk av medikamenter mot høyt blodtrykk kartlagt systematisk. På slutten av 1980-tallet ble spørsmål om andre medikamentgrupper inkludert på tilleggsskjemaer, men bare i begrensete geografiske områder. I Helseundersøkelsen i Hordaland 1997-1999 ble det satt større fokus på bruk av medikamenter. Spørsmål om bruk av legemidler (punktprevalens, preparatnavn) ble inkludert på hovedskjemaet med plass for å liste opp alle medisiner tatt dagen i forveien (inkludert grunn for bruk). Det ble også spurt om legemidlene ble tatt daglig eller ikke. I Helseundersøkelsen i Oslo 2000-2001 ble legemiddelspørsmålene videreutviklet og etablert på hovedskjemaet. Det nye designet består av en kombinasjon av spesifikke spørsmål om ulike legemiddelgrupper kombinert med åpne spørsmål om preparatnavn, diagnose og varighet. Bruk av blodtrykkssenkende og kolesterolsenkende midler ble kartlagt på samme måte som i tidligere studier. Alle helseundersøkelser fra Nasjonalt folkehelseinstitutt etter 2000 har benyttet tilsvarende design på legemiddelspørsmålene.
\end{abstract}

\section{Skurtveit S, Furu K, Rosvold EO, Straand J. Questions on drug use in health surveys - from single questions to general view. Nor J Epidemiol 2003; 13 (1): 137-146.}

\section{ENGLISH SUMMARY}

The drug use questions in Norwegian health surveys are presented in this paper. We have focused on the questions used in the health surveys connected to CONOR (COhort of NORway). The drug use questions have undergone extensive changes over the years from 1974 until now. From the beginning only questions about use of antihypertensives were included systematically on different geographic regions. In the late 80's questions about use of other drug categories were introduced. These questions were only included on supplementary questionnaires and in some geographical areas. In the Hordaland Health Study 1997-99, more attention were given to drug use questions. On the main questionnaire it was asked for point prevalence of drug use and trade names. Attendees were also asked if the drugs were used daily. In the Oslo Health Study 2000-2001 the drug use questions were developed further. Use of antihypertensives and cholesterol-lowering drugs were asked for in the same way as in previous studies. The new design consists of a combination of specific questions on the frequency of use of different drug categories, followed by an open question monitoring trade names, reason for taking and duration of treatment. This same design and handling of drug use questions has later been used in the successive population surveys performed by the Norwegian Institute of Public Health.

\section{INNLEDNING}

I 2002 utgjorde samlet legemiddelomsetning i Norge over 14 milliarder kroner (1). Omsetningen i kroner har de siste årene økt med 10-14\% hvert år. Omkring to tredjedeler av disse utgiftene dekkes av offentlige budsjett via Rikstrygdeverket (blåreseptordningen) og sykehus/sykehjem. Dette viser at behandling med legemidler er en av de viktige innsatsfaktorene i vårt helsevesen. Legemiddelbruk er en viktig indikator for helsetilstanden i befolkningen, men kan også representere en potensielt skadelig eksposisjon som i seg selv kan medføre negative helseeffekter.

Kunnskap om legemiddelbruken i Norge har til nå i all hovedsak basert seg på salgsstatistikk fra grossister til apotek (1). Slik statistikk gir imidlertid ingen informasjon om legemiddelbruken på individnivå. Nasjonale reseptdata har i liten grad blitt brukt til farmako- 
epidemiologisk forskning i Norge pga. begrenset tilgang til data fra apotekene. Det har imidlertid vært gjennomført undersøkelser basert på reseptdata (2-3), for eksempel i Møre og Romsdal hvor selvkopierende reseptblokker supplert med et kort spørreskjema ble benyttet i allmennpraksis gjennom 2 måneder (2). Norge har til nå ikke hatt et reseptbasert legemiddelregister, men dette er nå under etablering (4).

Bruk av medisiner kan også undersøkes i epidemiologiske studier av helseproblemer i populasjoner. I tillegg til informasjon om reseptpliktige medikamenter, kan slike helseundersøkelser hente inn informasjon om reseptfrie medikamenter, samt om helsetilstand, risikofaktorer og sosiodemografisk bakgrunn på individnivå. Informasjon om pasientspesifikke kliniske forhold er viktig i tolkningen av legemiddelbruk. Helseundersøkelsene gir oss mulighet til å sammenligne brukere og ikke-brukere av legemidler, og gir grunnlag for å studere sammenhengen mellom bruk av legemidler og relevante helsevariabler på individnivå.

Statens helseundersøkelser (SHUS, nå en del av Nasjonalt folkehelseinstitutt) har siden 1974, som ledd i program for forebygging av kardiovaskulære sykdommer, tilbudt systematiske helseundersøkelser i Norge til visse aldersgrupper i befolkningen. Undersøkelser har vært gjennomført i alle landets fylker, unntatt Oslo. I flere av fylkene har Statens helseundersøkelser samarbeidet med universitet og andre institusjoner i gjennomføringen av utvidede helseundersøkelser. Fordi helseundersøkelsene primært startet med kartlegging av kardiovaskulære sykdommer medførte det at bare spørsmål om bruk av legemidler mot høyt blodtrykk ble inkludert i de første undersøkelsene. Senere ble spørsmålene om bruk av legemidler forandret og videreutviklet. Fra og med Helseundersøkelsen i Oslo i 2000-2001 er samme standardiserte design på legemiddelspørsmålene blitt benyttet i senere helseundersøkelser fra Nasjonalt folkehelseinstitutt, så som i Oppland og Hedmark, i Troms og Finnmark, Tromsø og i "Helse- og levekårsundersøkelsen" i kommuner med samisk og norsk bosetting (5).

I denne artikkelen skal vi gi en oversikt over spørsmålene om bruk av medikamenter som er blitt benyttet i de store befolkningsundersøkelsene i regi av SHUS, nå Nasjonalt folkehelseinstitutt. Vi har valgt å fokusere spesielt på legemiddelspørsmålene i helseundersøkelsene som inngår i nettverket CONOR (COhort of NORway) (6).

\section{STUDIEN FRA DE TRE NORSKE FYLKENE (FINN- MARK, SOGN OG FJORDANE, OPPLAND)}

Mellom 1974 og 1988 ble det gjennomført hjertekarundersøkelser i Finnmark, Sogn og Fjordane og Oppland med et tidsintervall på 3-10 år. Undersøkelsene er detaljert beskrevet annet sted (7-12). På baksiden av invitasjonsbrevet var det trykket et spørreskjema som inkluderte spørsmål om røykevaner, fysisk aktivitet, kaffedrikking og matvaner, samt kardio- vaskulær sykehistorie og symptomer. Skjemaet ble fylt ut hjemme og medbrakt til undersøkelsen, der det ble kontrollert av en sykepleier. På spørreskjemaet ble det også stilt spørsmål om behandling for høyt blodtrykk (figur 1). Spørsmålet var stilt generelt for å kartlegge all behandling, inkludert medikamenter. Det ble ikke innhentet noen informasjon om varigheten av behandlingen og hvilket preparat som ble brukt. I tillegg ble det spurt om bruk av nitroglycerin (figur1). Ved den tredje undersøkelsen i disse fylkene ble kvinnelige deltagere intervjuet ved fremmøte om bruk av p-piller og hormoner i overgangsalderen. Alle brukere ble også spurt om å oppgi navnet på preparatet de brukte (12).

Det ble hovedsaklig brukt samme hovedspørreskjema ved undersøkelsene $\mathrm{i}$ de tre fylkene. I noen av undersøkelsene ble det imidlertid utformet tilleggsskjemaer for å samle inn data til spesifikke prosjekter. For ikke å influere på frammøtet til hovedundersøkelsen, ble tilleggsskjemaene først delt ut ved screeningen, eller de ble sendt noen uker etter at undersøkelsen var avsluttet. I tilleggsskjemaet brukt $\mathrm{i}$ Finnmark 3 undersøkelsen (1987-88), ble deltagerne spurt om bruk av spesifikke medikamentkategorier i løpet av de siste 14 dagene (figur 1).

Figur 1. Spørsmål om bruk av legemidler benyttet i hjertekarundersøkelser gjennomført mellom 1974-1988 i tre norske fylker (Finnmark, Sogn og Fjordane og Oppland).

\section{DE TRE NORSKE FYLKENE FINNMARK, SOGN OG FJORDANE, OPPLAND}

1974-1988, hovedskjema

Er DE under behandling for:

Høyt blodtrykk .................

Bruker DE:

Nitroglyserin

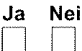

FINNMARK 3 1987-1988, tilleggsskjema

Har DE siste ár brukt tabletter, sprøyter

eller astmaspray mot astma eller allergi?

Har de brukt følgende medisiner siste 14 dager?

Ja Nei

Kryss av for hver medisin.

Smertestillende

Febersenkende

Eksemsalve

Syrenøytraliserende

Sovemedisin ......

Avføringsmidler

Medisin mot epileps

Annen medisin.

Bruker de tran regelmessig?

Sett kryss i den ruten som passer best.

Bruker ikke tran

Bruker tran bare i mørketida.

Bruker tran hele året .....

Bruker tran pả annen måte 


\section{0-ÅRINGSUNDERSØKELSENE}

I 1985 igangsatte SHUS de såkalte 40-åringsundersøkelsene (13-20). De startet i Østfold i 1985, og fra 1993 var programmet blitt landsdekkende, med unntak av Oslo som har hatt sitt eget opplegg (10). Medikamentspørsmålene i det første skjemaet som ble laget til undersøkelsene i fylkene Østfold og Aust-Agder i 1985 og 1986, ble noe endret i de etterfølgende 40åringsundersøkelsene (figur 2) (14). Blant annet ble det fra 1986 presisert at spørsmålet om blodtrykksbehandling gjaldt medikamentell behandling. I 1994 ble spørreskjemaet ytterligere endret for at det skulle tilpasses CONOR-programmet (10,6). I 1997 ble skjemaet utvidet til tre sider, og medikament-delen ble utvidet med spørsmål om bruk av kolesterolsenkende legemidler (figur 2). Kvinnene fikk fra 1985 muntlig spørsmål om menstruasjonsforhold og bruk av p-piller og østrogen når de møtte opp til undersøkelsen. Fra 1997 ble disse spørsmålene inkludert i hovedskjemaet (figur 2).

Tilleggsskjemaene som ble brukt ved "40-åringsundersøkelsene", inneholdt i varierende grad mer omfattende spørsmål om bruk av medisiner. Ved undersøkelsene i Østfold (1985 og 1988) og Aust-Agder (1986 og 1989) ble det stilt følgende spørsmål (14): "Hvor ofte har De brukt smertestillende medisin i løpet av siste måned?" med svaralternativene: a) daglig, b) hver uke, men ikke daglig, c) sjeldnere enn hver uke og d) ikke brukt siste måned. Tilsvarende spørsmål ble stilt om bruk av beroligende, nervetabletter og sovetabletter.

\section{UNDERSØKELSENE I TROMSØ OG NORD- TrøNDELAG}

Siden 1979 har SHUS medvirket til helsescreeningen ved flere andre undersøkelser, som helseundersøkelsene i Tromsø 2+3+4+5 i 1979-80; 1986-87; 1994-95 og 2001 (21) og i Nord-Trøndelag (HUNT 1 og 2) i 1984-86 og 1995-97 (22).

Undersøkelsene i Tromsø ble utført i samarbeid mellom Universitetet i Tromsø og SHUS. Ved undersøkelsene i 1979-80 og 1986-87 ble spørsmål om bruk av medikamenter mot høyt blodtrykk stilt på samme måte som i de "tre fylkesundersøkelsene" og i "40åringsundersøkelsene" (figur 1 og 2). I 1986-87 var spørsmål om bruk av medikamenter mer omfattende (21). Spørsmålene som ble stilt på tilleggsskjemaet var nokså like Finnmark 3 (figur 1), men legemiddelkategorier som syrenøytraliserende medikamenter og avføringsmidler, ble erstattet med blodtrykksmedisin, migrenemedisin og hjertemedisin. I tillegg ble følgende spørsmål stilt: "Har De siste år brukt tabletter, sprøyter eller astmaspray mot astma eller allergi", med svaralternativer ja eller nei.

Helseundersøkelsen i Nord-Trøndelag i 1984-86 omfattet alle innbyggerne som var 13 år og eldre (2225). Hovedmålet var å kartlegge forekomsten av høyt blodtrykk og diabetes, og å evaluere behandlingskvaliteten av blodtrykkspasienter, personer med diabetes og personer med tuberkulose. Hver deltaker fylte ut to spørreskjemaer. Figur 3 viser spørsmålene om bruk av medikamenter som ble stilt på hovedskjemaet. På tilleggsskjemaet ble det stilt spørsmål om bruk av medikamenter mot høyt blodtrykk og diabetes i utvidet form $(22,23)$.

Figur 2. Spørsmål om bruk av legemidler benyttet i 40åringundersøkelsene.

\section{0-ÅRINGSUNDERSøKELSENE}

\section{5-1986}

Er DE under behandling for:

Høyt blodtrykk

Bruker DE:

Nitroglyserin

1986-1994

Er DE under medikamentell behandling for høyt blodtrykk?

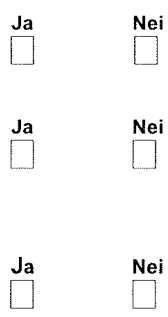

1994-1997

Bruker du medisin mot høyt blodtrykk?:

Nå .................................

Før men ikke ná

Aldri brukt.

Hvis ja, hvilket merke bruker du nå?

\section{7-1999}

Bruker du medisin mot høyt blodtrykk?:

Nả........

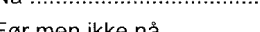

Aldri brukt .....

Hvis du bruker medisin nå, hvilke (t) merke bruker du?

Bruker du kolesterolsenkende medisin NA?: (Hvis nei, gå til 14. ETTERUNDERSøKELSE)

Hvor gammel var du da du begynte med

kolesterolsenkende medisiner?........................ Alder $i$ å

\section{Bruker du nå, eller har du tidligere brukt}

P-pille (også minipille) eller p-sprøyte ........

Vanlig spiral

Hormonspiral (pris ca. kr.1000)

$\emptyset$ strogen/progesteron ............................

(tabletter, plaster, sprøyte)

Østrogen (krem eller stikkpiller).

Til deg som bruker p-pille, hormonspiral (ikke vanlig spiral) eller hormoner i overgangsalderen NA:

Hvilke(t) merke(r) bruker du?

Omtrent hvor lenge har du brukt det du bruker nå?

Antall år $\square \square$ Hvis mindre enn ett år....Måneder 
Figur 3. Spørsmål om bruk av legemidler benyttet i Helseundersøkelsen i Nord-Trøndelag 1984-1986 (HUNT 1).

\section{NORD-TRøNDELAG, HUNT 1}

\section{HUNT 1 1984-1986, hovedskjema}

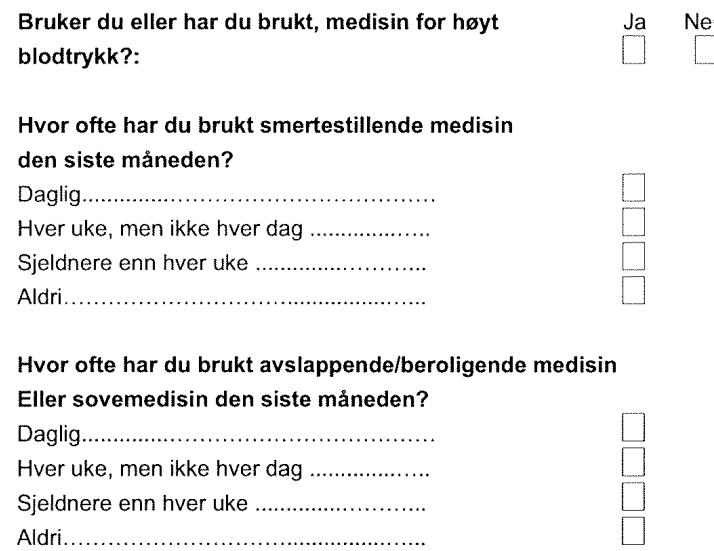

\section{COHORT OF NORWAY - CONOR}

Samling av data og biologisk materiale til CONOR startet i 1994 (6,10,26). Til dags dato (juli 2003) omfatter CONOR helsedata og blodprøver fra i underkant av 170000 personer. Oversikt, bakgrunnen for CONOR, samt målsetning og hvilke potensialer som ligger $\mathrm{i}$ dette datamaterialet er nærmere omtalt $\mathrm{i}$ to andre artikler i dette nummeret av Norsk Epidemiologi (26). Undersøkelser som inngår i CONOR er: Helseundersøkelsene i Tromsø (Tromsø 4 1994-1995); NordTrøndelag (HUNT 2 1995-1997), Hordaland (HUSK 1997-1999), Oslo (HUBRO 2000-2001), Oslo 2 2000, Oppland og Hedmark (OPPHED 2000-2001), Tromsø 5 (2001) og Troms og Finnmark (TROFINN 2002).

Bare spørsmål om bruk av medikamenter mot høyt blodtrykk inngår i CONORs felles sett av spørsmål (6), men fra 2000 har det blitt inkludert mer omfattende legemiddelspørsmål på hovedskjemaet. Disse er også brukt i de siste fem helseundersøkelsene som inngår i CONOR $(6,26)$.

\section{Tromso 4 (1994-95)}

Det ble samlet opplysninger og blodprøver fra 27000 kvinner og menn fra 25 år og oppover (21). Det ble brukt samme spørsmål om medikamenter mot høyt blodtrykk som i 40-åringsundersøkelsene, 1994-1997 (figur 4). I tilleggsskjema som ble delt ut ved undersøkelsen var det et eget felt der deltageren ble spurt om vedkommende hadde brukt diverse legemiddelkategorier periodevis daglig eller nesten daglig siste året. For hvert middel ble det også bedt oppgitt hvor mange av siste årets måneder legemiddelet hadde vært benyttet. Personer under 70 ble i tillegg spurt om de hadde brukt diverse kategorier av medisiner siste 14 dager (figur 4). Tilleggsskjemaet som ble delt ut blant dem over 70 år var av en enklere form (21).
Figur 4. Spørsmål om bruk av legemidler benyttet i Helseundersøkelsen i Tromsø 1994-1995 (Tromsø 4).

\section{TROMS $\varnothing 4$}

Tromsø 4 1994-1995, hovedskjema

Bruker du medisin mot høyt blodtrykk?:

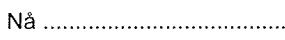

Før men ikke nả .................

Aldri brukt

Tromsø 4 1994-1995, tilleggsskjema

Har du det siste året periodevis brukt noen av de følgende midler daglig eller nesten daglig?

Angi hvor mange måneder du brukte dem.

Sett 0 hvis du ikke har brukt midlene.

Legemidler

Smertestillende .................................... mnd.

Sovemedisin ......................................... mnd.

Beroligende midler ................................ mnd.

Midler mot depresjon ..................................mnd.

Allergimedisin ...................................... mnd.

Astmamedisin .................................... mnd.

Kosttilskudd

Jerntabletter ......................................... mnd.

Kalktabletter eller benmel .......................... mnd.

Vitamin D tilskudd ................................ mnd.

Andre vitamintilskudd ............................ mnd.

Tran eller fiskeoljekapsler .......................... mnd.

Har du de siste 14 dager brukt følgende legemidler eller kosttilskudd? Sett ett kryss for hvert spørsmål

Legemidler

Smertestillende medisin

Febersenkende medisin

Migrenemedisin ..

Eksemsalve

Hjertemedisin (ikke blodtrykkmedisin) ...

Kolesterolsenkende medisin

Sovemedisin ...................................

Beroligende medisin ...

Medisin mot depresjon .

Annen nervemedisin .

Syrenøytraliserende midler

Magesármedisin

Insulin

Tabletter mot diabetes (sukkersyke)

Tabletter mot stoffskifte (thyroxin) .........

Kortisontabletter

Annen medisin.

Kosttilskudd

Jerntabletter

Kalktabletter eller benmel .........

Vitamin D- tilskudd ...

Andre vitamintilskudd

Tran eller fiskeoljekapsler

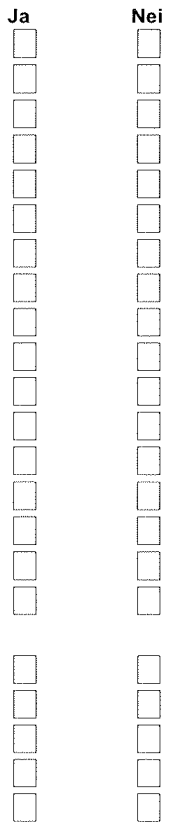

\section{HUNT 2 (1995-97)}

Forskningssenteret i Verdal koordinerer helseunders $\varnothing$ kelsene i Nord-Trøndelag. HUNT 2 var en oppfølger av Helseundersøkelsen i Nord-Trøndelag 1984-86 (HUNT 1) og dekket flere tema enn den første undersøkelsen (22). Også i HUNT 2 deltok fylkets innbyggere fra 13 år og oppover. Blodprøver ble tatt av deltakere over 20 år. Omtrent 70000 personer deltok. 
Spørsmål om bruk av medikamenter mot høyt blodtrykk, astma og for lavt stoffskifte ble stilt på hovedskjemaet, mens bruk av andre medikamentkategorier i løpet av de siste 12 måneder ble kartlagt ved hjelp av tilleggsskjemaene (figur 5). I tillegg ble det nøyere kartlagt bruk av avslappende/beroligende medisin eller sovemedisin den siste måneden. På skjemaet for kvinner i alder 20-69 år ble det spurt om bruk av p-piller.

Figur 5. Spørsmål om bruk av legemidler benyttet i Helseundersøkelsen i Nord-Trøndelag 1997-1999 (HUNT 2).

\section{NORD-TRøNDELAG}

\section{HUNT 2 1997-1999, hovedskjema}

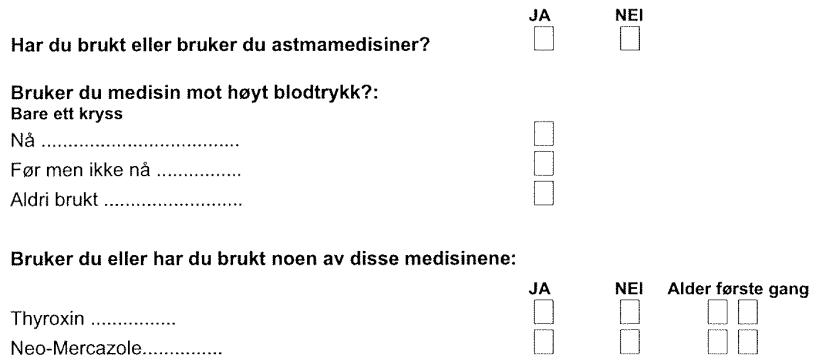

HUNT 2 1997-1999, tilleggsskjema

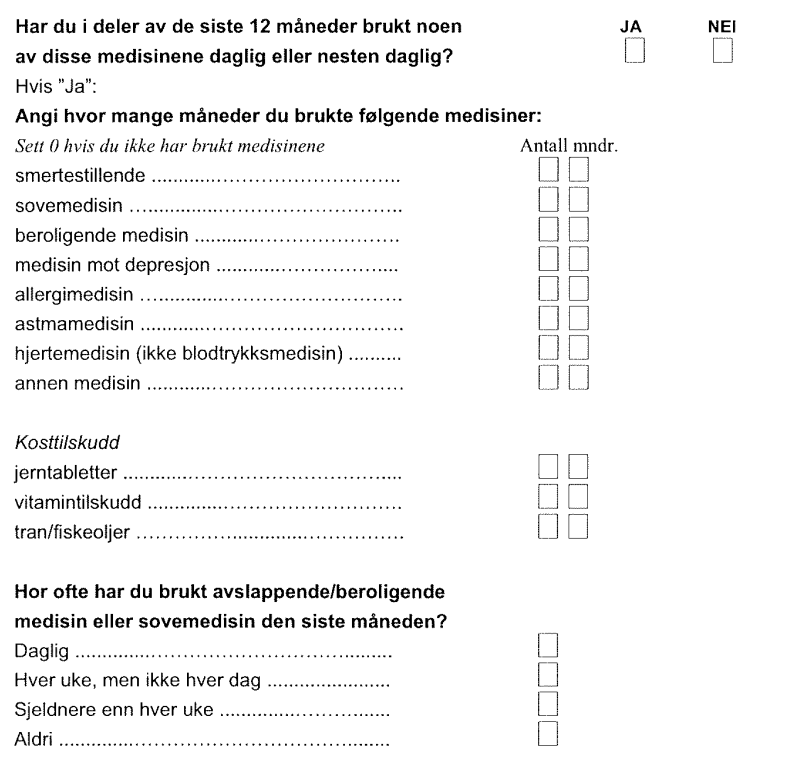

HUNT 2 1997-1999, tilleggsskjema - kvinner 20-69 år

Har du noen gang brukt p-piller, minipiller inkludert?
His "JA": Hvor gammel var du forste gang
du brukte p-piller?
Hvor lenge har du brukt p-piller i alt?
Hvis under ett ár, antall máneder
Bruker p-piller ná?
Hvilket merke bruker du?

\section{HUSK (1997-99)}

Helseundersøkelsen i Hordaland (HUSK) er en stor befolkningsundersøkelse basert på om lag 30000 inviterte personer $\mathrm{i}$ Hordaland fordelt med omkring $18000 \mathrm{i}$ aldersgruppen 40-48 år og resten i aldersgruppen 70-72 år (27). Undersøkelsen ble gjennomført av SHUS i samarbeid med Universitetet i Bergen.

Hver femte kvinne (40-48) år ble ved helseundersøkelsen dessuten invitert til å delta i en longitudinell studie, kvinnekohorten.

På hovedskjemaet som alle fylte ut, var det et eget felt med spørsmål om medisinbruk (figur 6). Medisiner ble forklart som alle slags medisiner, både reseptpliktige og reseptfrie legemidler, natur(lege)midler, vitaminer og mineraler. Videre medisin som svelges, inhaleres, injiseres, stikkpiller, salver, kremer eller dråper (figur 6).

I skjemaet som ble delt ut ved undersøkelsen (Kvinneskjema og Mannsskjema henholdsvis 1 og 2) var det et eget felt der deltageren ble spurt om vedkommende hadde brukt følgende midler siste året: smertestillende, sovemedisin, beroligende midler, midler mot depresjon, allergimedisiner, astmamedisin, jerntabletter, vitamintilskudd eller tran. For hvert middel ble det også bedt oppgitt hvor mange av siste årets måneder legemiddelet hadde vært benyttet.

Kvinnekohorten (2300 kvinner) har siden undersøkelsen startet, mottatt et årlig spørreskjema med blant annet de samme spørsmål om medisinbruk som på hovedskjemaet.

I HUSK inngår dermed opplysninger om medisinbruk som en omfattende tverrsnittsundersøkelse med punktprevalens ("medisiner tatt i går") hvor personens egen oppgitte grunn for bruk av hvert middel inngår. Dessuten ble det krysset av for om de ulike oppgitte legemidlene ble tatt daglig eller ikke. Videre en ettårsprevalens ("siste 12 måneder") i forhold til enkelte oppgitte grupper av legemidler og vitaminer mv. Og endelig en longitudinell kartlegging hos en gruppe kvinner (kvinnekohorten). Mer enn halvparten av alle deltagerne i HUSK oppgav bruk av ett eller flere legemidler. Seksjon for allmennmedisin ved Universitetet i Bergen hadde ansvaret for å kode medikamentdelen, herunder bruk av reseptfrie legemidler og alternative medisiner, samt personenes oppgitte grunner for medisinbruk. Legemidlene ble kodet i henhold til ATC (Anatomisk Terapeutisk Kjemisk)-klassifikasjonen (28), mens det for natur(lege)midler, homeopatmidler, vitaminer og mineraler mv. ble utarbeidet en egen kodeliste. Oppgitt grunn for medisinbruk ble kodet basert på en modifisert versjon av International Classification of Primary Care (ICPC) (29). I underkant av halvparten av alle deltagerne hadde brukt ett eller annet legemiddel dagen i forveien. Undersøkelsen er under bearbeiding og analyse og datakvaliteten på utfylte opplysninger om medisiner og grunn for bruk, vurderes som god. 
Figur 6. Spørsmål om bruk av legemidler benyttet i Helseundersøkelsen i Hordaland 1997-1999 (HUSK).

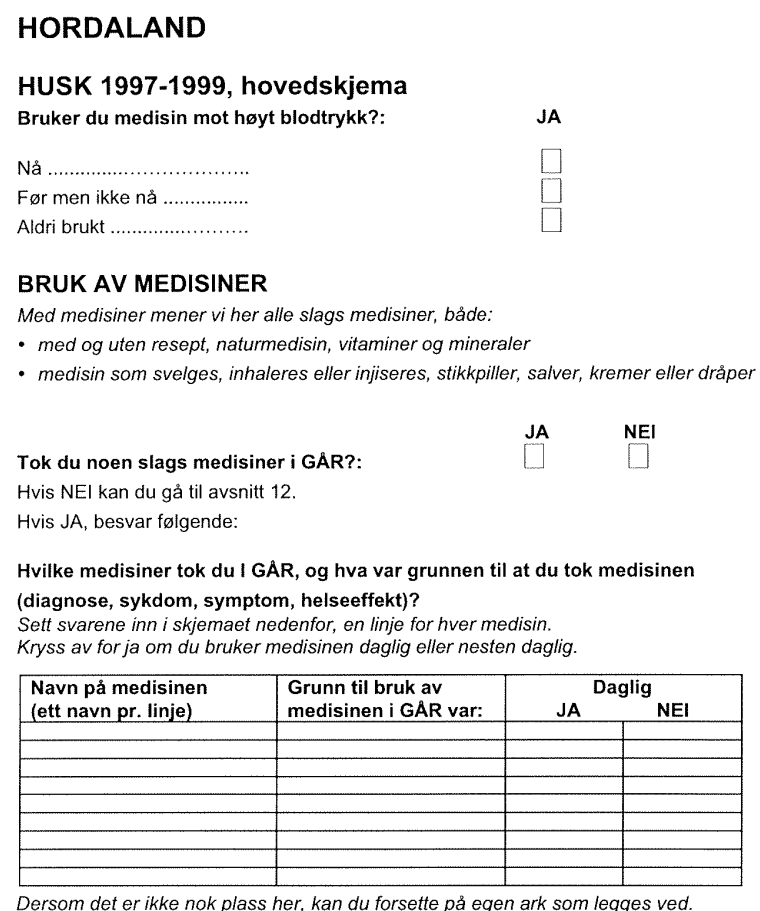

HUSK 1997-1999, tilleggsskjema

Har du i løpet av det siste áret brukt noen av følgende midler daglig eller nesten daglig?

Angi hvor mange måneder du brukte dem. Sett O hvis du ikke har brukt noen av midlene.

Legemidler

Smertestillende _... Antall måneder

Sovemedisin ...................................... Antall måneder

Beroligende midler ................................ Antall måneder

Midler mot depresjon ................................ Antall måneder

Allergimedisin ....................................... Antall måneder

Astmamedisin .......................................... Antall måneder

Kosttilskudd

Jerntabletter ........................................ Antall måneder

Vitamintilskudd ........................................ Antall mảneder

Tran .................................................... Antall måneder

HUSK 1997-1999, tilleggsskjema - kvinner Bruker du ná, eller har du brukt

P-pille (også minipille)

Hormonspiral ......

eller plaster)

Østrogen (krem eller stikkpiller)

Hvis du bruker p-pille, hormonspiral eller østrogen, hvilket merke bruker du?

Svarprosenten på de årlige to-siders spørreskjemaene sendt ut til kvinnekohorten (konsesjon fram til år 2012) ligger så langt på omkring $90 \%$.

\section{HUBRO (2000-2001)}

Helseundersøkelsen i Oslo 2000-2001 (HUBRO) ble utført av SHUS i samarbeid med Universitetet i Oslo og Oslo kommune (5). Studiepopulasjonen inkluderte alle individer bosatt i Oslo og født i 1924/25, 1940/41, 1955, 1960 og 1970. Omtrent 18800 personer deltok i undersøkelsen (5).
Legemiddelspørsmålene som inngikk i hovedskjemaet (4), var firedelt (figur 7). Del 1 dekket nåværende eller tidligere bruk av medisiner mot høyt blodtrykk og kolesterolsenkende medisiner. Del 2 dekket frekvens av bruk de siste fire uker av legemiddelgruppene smertestillende på og uten resept, beroligende medisin, sovemedisin og medisin mot depresjon, samt annen medisin på resept. I del 3 ble respondenten bedt om å angi navnene på medikamentene de hadde krysset av for, hvilke plager medikamentene ble brukt mot, og om de hadde brukt disse medikamentene i over eller under ett år. I del 4 ble kvinnelige deltakere spurt om bruk av hormoner og p-piller. Også her ble det spurt om preparatnavn. Det har blitt gjort et omfattende kodearbeid etter ATC-klassifikasjonssystemet (28). Årsak til bruk ble kodet etter ICPC-diagnosesystemet for primærhelsetjenesten (29). Det ble kodet opp til 10 medikamenter for hver deltaker.

75-åringene i undersøkelsen fikk en noe endret utgave av medikamentspørsmålene: De ble spurt om bruk av insulin og tabletter mot sukkersyke, samt om medisin mot osteoporose. Videre ble det i spørsmålet om smertestillende medisin ikke skilt mellom reseptbelagte og reseptfrie legemidler. Spørsmål om bruk av østrogenmedisin ble også tilpasset denne aldersgruppen. På tilleggsskjemaene til 40- og 60-åringer er det inkludert detaljerte spørsmål om bruk av legemidler ved dyspepsi og magesår, samt spørsmål om relevante kliniske symptomer (5).

Legemiddelspørsmålene på hovedskjemaet i HUBRO er videreutviklet med utgangspunkt i legemiddelspørsmålene som har vært benyttet $\mathrm{i}$ de ulike helseundersøkelsene tidligere, blant annet i Tromsø, Nord-Trøndelag, og i HUSK. Spørsmålene er bearbeidet og utviklet for å kunne gi svar på flere problemstillinger. Det er valgt en måleperiode på fire uker med angivelse av frekvens fordi det er ønskelig å se på forskjellene mellom regelmessige og sporadiske brukere av legemidler. Spørsmål som begrenser seg til kun daglige/nesten daglige brukere siste måned vil primært fange opp regelmessige brukere. Spørreskjemaet inkluderer også et mer detaljert spørsmål om preparatnavn på legemidlene samt årsaken til bruken av det enkelte preparat. Grupper av legemidler gir ingen sikker angivelse av hva slags medikament personen faktisk tar. Man får imidlertid indikasjon på hvilke lidelser/plager pasienter oppfatter at medikamentet skal hjelpe mot. En kombinasjon av spørsmål om legemiddelgruppe, samt oppfølgingsspørsmål om preparatnavn og diagnose/symptom, vil gi både en validering av gruppespørsmålene, samt utfyllende opplysninger om årsak til bruk.

\section{Oslo 2, OPPHED, Tromso 5 og TROFINN}

I Oslo 2 undersøkelsen og i de senere undersøkelsene OPPHED, Tromsø 5 og TROFINN er det benyttet samme standardiserte design på legemiddelspørsmålene og omfattet samme aldersgrupper som i HUBRO. 
Det er første gang slike detaljerte spørsmål om legemiddelbruk er anvendt på ulike populasjoner fra ulike deler av Norge, men i samme aldersgrupper.

Samme design på legemiddelspørsmål brukes også i følgende undersøkelser: "Helse- og levekårsundersøkelsen" i kommuner med samisk og norsk bosetting og helseundersøkelsene i Romsås og Furuset (MoRo `2001`og `2003’) (5).

Figur 7. Spørsmål om bruk av legemidler benyttet i Helseundersøkelsen i Oslo 2000-2001 (HUBRO).

\section{OSLO}

\section{HUBRO 2000-2001, hovedskjema}

Del 1

Med medisiner mener vi her medisiner kjøpt på apotek.

Kosttilskudd og vitaminer regnes ikke med her.

Bruker du?

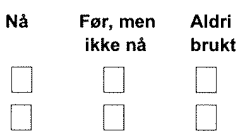

Medisin mot høyt blodtrykk

Kolesterolsenkende medisin

Del 2

Hvor ofte har du i løpet av de siste 4 ukene brukt følgende medisiner? (Sett ett kryss pr. linje)

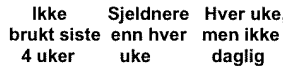

\begin{tabular}{|c|c|c|c|}
\hline & uke & daglig & Daglig \\
\hline Smertestillende uten resept ........ & $\square$ & D & 0 \\
\hline Smertestillende på resept... & $\square$ & $\square$ & [ \\
\hline Sovemedisin ...... & $\square$ & $\square$ & \\
\hline Beroligende medisin ........................ & $\square$ & $\square$ & $\square$ \\
\hline Medisin mot depresjon ................ & $\square$ & [] & $\square$ \\
\hline Annen medisin pả resept......... & $\square$ & $\square$ & $\square$ \\
\hline
\end{tabular}

Del 3

For de medisinene som du har krysset av for i pkt 13.1 og 13.2, og som du har brukt i lopet av de siste 4 ukene: Angi navnet og hvilken grunn det er til at du tar/har tatt disse (sykdom eller symptom)

(Kryss av for hvor lenge du har brukt medisinen) Hvor lenge har do Grun til bruk av medisinen: brukt medisinen?

Navn pá medisinen: Grunn til bruk av medisinen: Inntil Etta àr (ett navn or linie).

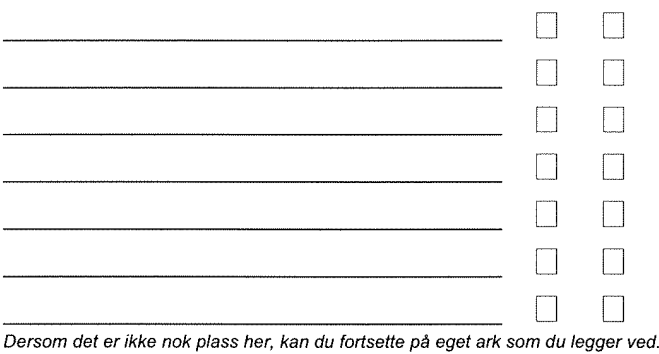

Del 4

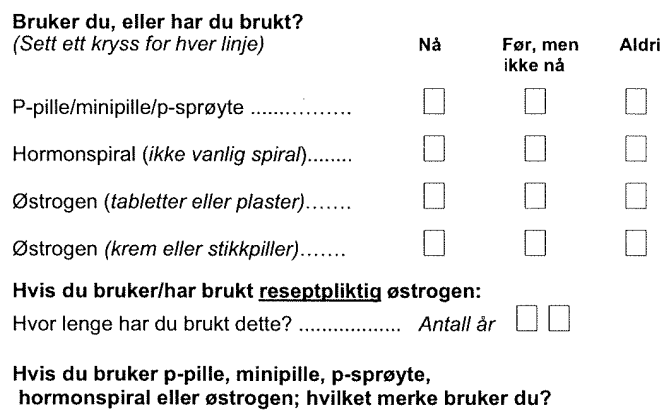

\section{HELSEUNDERSØKELSER BLANT 15-16-ÅRINGER}

Samtidig med helseundersøkelsen av de voksne i Oslo 2000-2001 ble det gjennomført en helseundersøkelse blant ungdommer, UNGHUBRO (30). Denne inkluderte alle individer i 10 . klasse som sto oppført på klasselistene for hver enkelt skole i Oslo i årene 20002001. Alle elevene fylte ut to spørreskjemaer i løpet av to skoletimer. Spørreskjemaene omfattet spørsmål om ulike helsevaner, inkludert bruk av ulike medikamenter. Det er brukt samme design på legemiddelspørsmål (del 2-4) som for voksne, men det er tilføyd spørsmål om bruk av astma- og allergimedisin.

De samme legemiddelspørsmålene inngår i tilsvarende undersøkelser blant 15-16-åringer som er gjennomført i tilknytning til OPPHED, TROFINN, Tromsø 5 og i "Helse- og levekårsundersøkelsen" i kommuner med samisk og norsk bosetting (30).

\section{LEGEMIDDELDATA FRA HELSEUNDER- SØKELSER OG FARMAKOEPIDEMIOLOGISK FORSKNING}

I denne artikkelen har vi gitt en oversikt over legemiddelspørsmålene som har vært brukt i ulike helseundersøkelser gjennomført i regi av SHUS, eller hvor SHUS var samarbeidspartner med andre institusjoner. Vi har fokusert på spørsmålene som ble stilt på hovedskjemaet som ble sendt ut sammen med invitasjonsbrevet. Spørsmål om legemiddelbruk er også inkludert i tilleggsskjemaer som vanligvis deles ut ved screeningen - og i noen tilfeller bare til avgrensede deler av populasjonen. Disse representerer spesifikke, avgrensede prosjekter, og vi har her valgt å presentere bare enkelte av legemiddelbruksspørsmålene som inngår på tilleggskjemaene.

Oversikten viser at kartleggingen av legemiddelbruk ved hjelp av helseundersøkelsene har gjennomgått store forandringer. Ved de første undersøkelsene ble bare bruk av medikamenter mot høyt blodtrykk kartlagt systematisk over forskjellige geografiske områder i Norge. Spørsmål om bruk av andre medikamentgrupper ble inkludert bare på tilleggsskjemane, og bare i enkelte områder (Finnmark 3-undersøkelsen). Senere ble det satt fokus på smertestillende-, beroligende- og sovemedisiner. Eksplisitt spørsmål om bruk av kolesterolsenkende legemidler ble inkludert i 1997 i "40-års undersøkelsene", men spørsmålet var ikke inkludert i de første undersøkelser som inngår i CONOR (HUSK og HUNT 2).

I HUSK-undersøkelsen ble det satt større fokus på bruk av medikamenter. Spørsmål om bruk av legemidler (punktprevalens, preparatnavn) ble inkludert på hovedskjemaet med plass for å liste opp alle medisiner tatt dagen i forveien (inkludert grunn for bruk). Legemidlene ble kodet etter ATC-klassifikasjonen. Spørsmålet omfattet dessuten også bruk av reseptfrie legemidler, kosttilskudd, vitaminer, mineraler, natur(lege)- 
midler, homeopatiske midler mv. Om midlene ble tatt fast (daglig) eller ikke ble også krysset av. Det ble dessuten stilt mer spesifikke legemiddelspørsmål på tilleggsskjemaene.

Fra HUBRO-undersøkelsen 2000-2001 er et firedelt spørsmål om bruk av legemidler etablert på hovedskjemaet. Frekvensen av bruk i løpet av fire uker av ulike kategorier av medikamenter ble kartlagt i tillegg til bruk av medisiner mot høyt blodtrykk, kolesterolsenkende medikamenter, p-piller og østrogen. Et åpent spørsmål om prepratnavn, diagnose og varighet ble også inkludert. En annen artikkel i dette nummer av tidsskriftet viser en høy intern responsrate på legemiddelspørsmålene, fra vel $80 \%$ på spørsmål om bruk av antidepressiva til nesten $100 \%$ på både blodtrykkssenkende og kolesterolsenkende legemidler (31).

Farmakoepidemiologisk forskning de siste 20 årene hvor data fra helseundersøkelser er brukt, har fokusert på medikamenter mot høyt blodtrykk (32-37), men det er også gjennomført studier på andre kategorier av medikamenter som insulin og andre medikamenter mot sukkersyke (38), psykofarmaka (39-40), smertestillende medikamenter $(41,42)$, antacida (43) og p-piller/ hormoner (12,19-20). En mer detaljert oversikt er tidligere presentert av A.E. Eggen i et temanummer av Norsk Epidemiologi (44).

På grunn av manglende sammenlignbare data på legemiddelbruk, har de fleste studier fokusert bare på et geografisk område. Nasjonale oversikter over salg av eksempelvis psykofarmaka og kolesterolsenkende medikamenter viser store fylkesvise variasjoner, etter som de nordligste fylkenes forbruk bare representerer omkring halvparten av forbruket til enkelte fylker på Østlandet (1).

Etter 2000 har spørsmål om bruk av legemidler i befolkningsundersøkelsene blitt mer standardisert og brukt i forskjellige geografiske områder. Dette gjør det enklere å gjennomføre sammenlignbare studier av legemiddelforbruk mellom ulike geografiske områder, og letter mulighetene for å kombinere resultater fra flere helseundersøkelser.

Stortinget har vedtatt å opprette et reseptbasert pseudonymt legemiddelregister, og Nasjonalt folkehelseinstitutt er ansvarlig for etableringen. Registeret skal etter planen være i drift fra januar 2004. Ved å bruke en felles pseudonymiseringsprosedyre vil det $i$ prinsippet være mulig å sammenstille ("datakoble") opplysninger fra dette reseptregisteret til ulike helseundersøkelser (befolkningsundersøkelser) og andre helseregistre (Kreftregisteret, Medisinsk Fødselsregister, Dødsårsaksregisteret mv.). På denne måten vil man for eksempel kunne studere utvikling av legemiddelbruk på individnivå over tid og analysere legemiddelbruk i forhold til andre relevante helsevariabler som ikke finnes i reseptregisteret. Dette kan åpne opp for nye muligheter for farmakoepidemiologisk forskning $\mathrm{i}$ Norge. Uten en slik mulighet til å sammenstille data mellom reseptregisteret og andre helseregistre, vil imidlertid et reseptregister ha begrenset verdi som et forskningsregister.

\section{REFERANSER}

1. Rønning M, red. Legemiddelforbruket i Norge 1998-2002. Nasjonalt folkehelseinstitutt, 2003: 1; ISBN 828082-041-8.

2. Straand J. To prescribe or not to prescribe - drug prescribing studies from general practice. The Møre \& Romsdal Prescription study. Norsk Epidemiologi 1999; 9 (suppl 2): 1-123.

3. Eggen AE, Andrew M. Use of codein analgesics in a general population. A Norwegian study of moderately strong analgesics. Eur J Clin Pharmacol 1994; 46: 491-496.

4. Furu K. Drug utilisation in a public health perspective: Establishing a national prescription register in Norway. Norsk Epidemiologi 2001; 11 (1): 55-60.

5. Nasjonalt folkehelseinstitutt. Helseundersøkelser. http://www.fhi.no/tema/helseundersokelse/. Juli 2003.

6. Nasjonalt folkehelseinstitutt. Helseundersøkelser. Cohort of Norway. http://www.fhi.no/tema/conor/.

7. Bjartveit K, Foss OP, Gjervig T, Lund-Larsen PG. The cardiovascular disease study in Norwegian counties. Background and organization. Acta Med Scand 1979; (suppl 634): 1-70.

8. Bjartveit K, Foss OP, Gjervig T. The Cardiovascular Disease Study in Norwegian Counties. Results from first screening. Acta Med Scand 1983; (suppl 675): 1-184.

9. The cardiovascular disease study in Norwegian counties. Results from second screening. National Health Screening Service, Oslo 1988.

10. Bjartveit K. Statens helseundersøkelser. Fra tuberkulosekamp til mangesidig epidemiologisk virksomhet. Norsk Epidemiologi 1997; 7: 157-174.

11. Westlund K, Søgard AJ. Helse, livsstil og levekår i Finnmark. Resultater fra hjerte-karundersøkelsen i 1987 88 Finmark III. 1993. ISBN 82-90262-32-9.

12. Graff-Iversen S, Stensvold I, Lund-Larsen PG, Nodarse LO, Tverdal A, Urdal P. Serum lipids in postmenopausal or perimenopausal women using estrogen alone, estrogen with levonorgestrel, or estrogen with norethisterone, compared with nonusers: Results from a cross-sectional study in two Norwegian counties 1985-1988. J Clin Epidemiol 1998; 51 (2): 1311-1316. 
13. Nasjonalt folkehelseinstitutt. Helseundersøkelser. 40-årings-undersøkelsene. http://www.fhi.no/tema/ helseundersokelse/40/. Juli 2003.

14. Statens helseundersøkelser, Fylkeslegen i Østfold, Fylkeslegen i Aust-Agder: Helseundersøkelsene i Østfold 1985 og 1988 og i Aust-Agder 1986 og 1989. Statens helseundersøkelser, Oslo 1997.

15. Tverdal A, Selmer RM. 40-åringsundersøkelsene - 400000 menn og kvinner har møtt opp. Tidsskr Nor Loegeforen 2002; 122: 2641-2642.

16. Bjartveit K, Stensvold I, Lund-Larsen PG, Gjervig T, Krüger $\varnothing$, Urdal P: Hjerte- og karundersøkelser i norske fylker. Bakgrunn og gjennomføring. Status 1986-90 for risikomønster blant 40-42 åringer i 14 fylker. Tidsskr Nor Loegeforen 1991; 111: 2063-2072.

17. Statens helseundersøkelser: Håndbok for hjerte-karundersøkelsen. 40 åringsprosjektet, Oslo 1987.

18. Bjartveit K, Stensvold I, Lund-Larsen PG, Graff-Iversen S, Urdal P. Hjerte- og karundersøkelser i norske fylker. Utvikling 1985-90 av risikomønster blant 40-42 åringer i fire fylker. Tidsskr Nor Lageforen 1991; 111: 2072-2076.

19. Graff-Iversen S. 40 år gamle kvinner som bruker hormonregimer - sunne utvalg eller risikogrupper? Resultater fra helseundersøkelser i 11 norske fylker 1997-99. Norsk Epidemiologi 2001; 11: 73-79.

20. Graff-Iversen S, Tonstad S. Association of progestogen-only use with cardiovascular risk factors in 40-42year old women. Results of a population-based survey. Contraception 2002; 66: 7-13.

21. Universitetet i Tromsø. Tromsøundersøkelsen. http://www.ism.uit.no/tromso5/. Juli 2003.

22. Helseundersøkelsen i Nord-Trøndelag. http://www.hunt.folkehelsa.no/. Juli 2003.

23. Holmen J, Midthjell K, Bjartveit K, Hjort PF, Lund-Larsen PG, Moum T, Næss S, Waaler HT. The NordTrøndelag Health Survey 1984-86. Helsetjenesteforskning, Report No. 4, Senter for samfunnsmedisinsk forskning, Verdal 1990.

24. National Health Screening Service, Oslo, Health Services of Nord-Trøndelag County, Ullevål Hospital, Central Laboratory, Oslo: The cardiovascular disease survey in Nord-Trøndelag, 1989. Oslo 1991.

25. Midthjell K, Holmen J, Bjørndal A, Lund-Larsen PG: Is questionnaire information valid in the study of a chronic disease such as diabetes? The Nord-Trøndelag diabetes study. J Epidemiol Community Health 1992; 46: $537-42$.

26. Engeland A, Søgaard AJ. CONOR (Cohort Norway) - en oversikt over en unik forskningsdatabank. Norsk Epidemiologi 2003; 13: 73-77.

27. Universitet i Bergen. Helseundersøkelsen i Hordaland. http://www.uib.no/isf/husk/. Juli 2003.

28. Guidelines for ATC classification and DDD assignment. WHO Collaborating Centre for drug Statistics Methodology, Oslo 2000.

29. Lamberts H, Wood M, Hofmans-Okkes I (eds), The international classification of primary care in the European community with a multi-language layer. Oxford: Oxford medical publication, Oxford University Press, 1993.

30. Nasjonalt folkehelseinstitutt. Helseundersøkelser. Ungdomsundersøkelsene. http://www.fhi.no/tema/ helseundersokelse/ungdomsunders/. Juli 2003.

31. Furu K, Skurtveit S, Rosvold EO. Drug use questions in Norwegian health surveys - response rate and agreement between specific and open-ended questions. Norsk Epidemiologi 2003; 13: 147-154.

32. SHUS-NOTAT 1/89. A note on the epidemiology of blood pressure treatment in Norway. National Health Screening Service, Oslo 1989.

33. Thürmer H, Lund-Larsen PG, Tverdal A, Thelle DS. Treatment of hypertension as a risk factor in a prospective study. Int J Risk Safety Med 1990; 1: 267-278.

34. Thürmer H, Lund-Larsen PG, Tverdal A. Is blood pressure treatment as effective in a population setting as in controlled trials? Results from a prospective study. J Hypertension 1994; 12: 481-490.

35. Tverdal A: Er blodtrykksbehandling like effektiv i befolkningen som kontrollerte forsøk? Hjerteforum 1995; 8: 33-35.

36. Thürmer H, Tverdal A, Lund-Larsen PG. Er blodtrykksbehandling like effektivt i befolkningen som i kontrollerte forsøk? Tidsskr Nor Lageforen 1995; 115: 102-103.

37. Thelle DS: Er blodtrykksbehandlingen farligere enn sitt rykte? Tidsskr Nor Lageforen 1991; 111: 14-15.

38. Midthjell K, Holmen J, Bjørndal A. Types of diabetes treatment in a total, Norwegian, adult population. The Nord-Trøndelag diabetes study. J Intern Med 1994; 236 (3): 255-261.

39. Bjørndal A, Forsen L. A Forbruk av psykofarmaka i Norge. Kartlegging og analyser. Statens Institutt for Folkehelse, Seksjon for helsetjenesteforskning, 1990, Rapport nr.7.

40. Rosvold EO, Vaglum P, Moum T. Use of minor tranquilizers among Norwegian physicians. A nationalwide comparative study. Soc Sci Med 1998; 46 (4-5): 581-590.

41. Eggen AE. The Tromsø study: Frequency and predicting factors of analgesic drug use in a free-living population (12-56 years). J Clin Epidemiol 1993; 46: 1297-1304. 
42. Eggen AE. The use of controlled analgesics in a general population (15-59 years) - The influence of age, gender, morbidity, lifestyle and sociodemographic factors. Pharmacoepidemiol Drug Saf 1996; 5 (2): 101111.

43. Furu K, Straume B. Use of antacids in a general population: the impact of clinical variables, lifestyle and sociodemographic characteristics. J Clin Epidemiol 1999; 52: 509-516.

44. Eggen AE. The application of population based health surveys in pharmacoepidemiologic studies in Norway. Norsk Epidemiologi 2001; 11 (1): 41-46. 